UDC 331.366-053.6:341.123

CERIF: S150

\author{
Marko Novaković, $\mathrm{PhD}^{*}$
}

\title{
UNITED NATIONS INTERNSHIP PROGRAMME POLICY AND THE NEED FOR ITS AMENDMENT
}

An internship at the United Nations is an opportunity that young people interested in international law, international relations, and many other fields, perceive as he best possible career starting point - and rightfully so. The United Nations internship is an experience second to none in the world of international organizations and this is why it must be available to the widest range of people, regardless of their status, place of birth and social context. However, the current United Nations internship policy is very controversial and in desperate need of a change. While voices for change of policy are raised more and more, this topic has been very rarely addressed in academic literature across the world and papers and books dealing exclusively with this issue are almost non-existent. In this article, the author will address the main points of the concern regarding unpaid internship and will offer potential solutions for its improvement. This article is a humble contribution that will hopefully instigate wider academic acknowledgment of this problem and eventually contribute to the resolution of this unfortunate practice.

Key words: Internship. - United Nations. - Policy. - Fair. - Amendment. - Unpaid. - Least Developed Countries (LDP).

\section{INTERNSHIP AS A GENERAL NOTION}

The informal notion of internship was present in some form probably since the first jobs emerged, but one of the first normative acts to formally institutionalize it, was the Fair Labor Standards Act passed in the United States in 1938. ${ }^{1}$ US president Franklin Delano Roosevelt considered it "the most far-reaching, farsighted program for the benefit of

* Research Fellow, Institute of International Politics and Economics, Belgrade, marko@diplomacy.bg.ac.rs. 
workers ever adopted in this or any other country." 2 This law was passed during the Great depression and it aimed to protect the rights of workers through the introduction of a minimum wage, preventing long working hours without appropriate remuneration and child-labor. ${ }^{3}$

An internship is a very important, initial career step and intern's benefits are numerous. Interns can gain experience, develop skills, make connections, strengthen their resumes, learn about a field and assess their interest and abilities. Because of all these opportunities, the selection process for interns must be highly transparent and based solely on the quality of the candidates. This is especially true and important for the United Nations, the organization that has, since its founding in 1945 been a leader in the struggle to make the world a better place. ${ }^{4}$

\section{UN INTERNSHIP}

In the UN system, interns are still classified under a decades-old administrative instruction known as "gratis personnel" - a term originally invented for peacekeeping troops lent by governments to the organization. ${ }^{5}$ Gratis personnel are staff loaned to the United Nations, free of charge, by Member States. General Assembly resolution 51/243 of 15 September 1997 prescribes the circumstances under which such personnel may be utilized. Although interns constitute the majority $(89.4 \%$ according to a 2014/2015 report) of the "gratis personnel" there are also other groups included into this designation such as associate experts, technical cooperation experts and a heterogeneous group classified as Type II. ${ }^{6}$

\subsection{UN Intership and the selection of the best}

Since the League of Nations and the first years of the United Nations, one of the most important goals, in the formation of the administrative apparatus, was to attract as many top level experts as possible. At a

1 C. Durrant, "To Benefit or Not To Benefit: Mutually Induced Consideration As A Test For The Legality Of Unpaid Internships", University of Pennsylvania Law Review 1/2013, 169.

2 L. Fitzpatrick, "The Minimum Wage", Time, July 24/2009, http://www.time. com/ time/magazine/article/o, 9171,1912408,00. Html, last visited 29 October 2017.

3 E. M. Dodd, "The Supreme Court and Fair Labor Standards, 1941-1945”, Harvard Law Review 59/1946, 321.

4 J. Fomerand, The A to $Z$ of the United Nations, The Scarecrow Press 2009, vi.

5 Composition of the Secretariat: gratis personnel, retired staff and consultants and individual contractors Report of the Secretary-General, A/71/360/, 12-86.

6 Ibid. 
time, the League of Nations was a new organization, the first "international" and "global" institution. As such, employees of the League of Nations and in early years of the UN had to have, in addition to their job qualifications, certain dose of adventurism and intrinsic altruism. Employment in the League of Nations or the early days of the United Nations represented a risk of devoting years to a new and thus insecure environment for a greater cause (world peace and equality).

The United Nations have repeatedly addressed the issue of economic inequality stating that "one of the greatest discrimination in this world today is discrimination by rich people against poor people. ${ }^{7}$ This firm position comes with a responsibility as well, because the UN has to implement proclaimed values within its own system. Unfortunately, in the case of internships, these economic equality considerations while formally adhered are de facto are violated.

The reason for this conclusion relies on the fact that internships at the UN are not paid positions. Since internships are not paid, the interns must obtain means of funding their own accommodations, meals, transportation, health insurance and all other costs. The provision of the UNDP, similar to the provision of almost every UN agency confirming this policy, states "UNDP does not pay for internships. The costs associated with the latter must be borne by the nominating institution, related institution or government, which may provide the required financial assistance to its students; or by the student, who will have to obtain financing for subsistence and make his or her own arrangements for travel, accommodation etc.". 8

By not providing any financial support for the internship, there are a very limited number of people who can get the internship position. Selection process for the internship positions should be highly competitive, but main condition must be quality of the candidate not its wealth. Although the possibility of becoming an intern is theoretically available to everyone, it is actually limited to roughly three groups. First are the ones belonging to the very limited portion of a population whose families and general surroundings of their upbringing can provide them with sufficient funds to spend several months or more in an expensive cities such as Vienna, New York or Geneva. The second group is made of the people who live in the vicinity of above-mentioned cities (and other cities where UN offers internship programmes), so that they do not have to pay the accommodation and travel costs. The third group includes young people able to obtain funds from third parties (not themselves or the UN). This

7 J. Carter, B. Boutros-Ghali (eds.), Conference for Global Development Cooperation: Meeting Report, DIANE Publishing, 1992, 9.

8 http://www.undp.org/content/undp/en/home/operations/jobs/types-of-opportunities/internships.html, last visited 29 October 2017. 
sponsor can be their government, some international foundation, etc. A good example of this is Germany, where UN interns are supported by the Carlo-Schmid Programm. ${ }^{9}$ However, although this is the only one out of the three mentioned possibilities that actually provide some kind of meritbased selection, the issue remains that in the case of sponsorships somebody else is choosing interns for the UN.

It is obvious that according to the current internship policy, internship positions are de facto reserved mostly for young people coming from the Western countries or other most powerful economies. Just a casual glance at the list of countries with more than 100 interns in 2015 will demonstrate this. Moreover, this list offers a clear correlation between the wealth of the countries from which the interns are coming and their sheer number. There are 13 countries that provided 100 or more interns in 2015. The leader on this list was China 517 with interns, followed by the USA (434), France (314), Kenya (278), Germany (226), Italy (174), Canada (167), South Korea (159), the United Kingdom (140), the Russian Federation (135), Australia (133), Chile (107) and Spain (102). ${ }^{10}$ Despite the fact that interns are not part of the UN administration, one cannot neglect the fact that UN charter provision stating "...Due regard shall be paid to the importance of recruiting the staff on as wide a geographical basis as possible"11 is bluntly ignored when it comes to the internship positions.

On this list we can see two countries that clearly stand out - Chile and Kenya. These two countries are far from the rest of the group when it comes to the economic power, GDP and other economic parameters. The reason why those two countries are on the list, is not an effort to conform to article 101(3) of the UN Charter. Interns from Kenya and Chile are so numerous because their countries host UN offices that have internship programmes - one is in Santiago de Chile and the other one is in Nairobi (other main locations being New York (United States of America), Geneva (Switzerland), Vienna (Austria), Addis Ababa (Ethiopia), Bangkok (Thailand), Beirut(Lebanon)). ${ }^{12}$ For the same reason, there were 65 interns from Lebanon compared to only 2 interns from Costa Rica, despite the fact that those two countries have roughly the same GDP. ${ }^{13}$ Finally, there are some states that are so poor that their nationals are almost entirely prevented from doing internships despite the fact that they

9 https://www.studienstiftung.de/carlo-schmid/2 last visited 29 October 2017.

10 Engagement of type I gratis personnel, by nationality, category and gender: 2014-2015, Composition of the Secretariat: gratis personnel, retired staff and consultants and individual contractors Report of the Secretary-General, A/71/360.

11 Article 101(3), UN Charter.

12 https://careers.un.org/lbw/home.aspx? viewtype $=I P$, last visited 29 October 2017.

13 https://unstats.un.org/unsd/snaama/dnlList.asp, last visited 29 October 2017. 
have internship programs available within their country - Ethiopia had only 10 interns. This picture demonstrates direct correlation between economic power of the countries and number of interns. Aside from already mentioned disadvantage of people of lower economic status, current UN internship policy programme gives unequal and unfair treatment to the nationals of the poorest countries and this issue must be addressed rapidly - less than $6 \%$ of all the interns come from the least developed countries.

Apart from this main reason for the amendment of the internship programme policy, and that is equality, there is another argument for the change that solely relates to the UN administration. The UN administration frequently reports the departure of the most promising young interns. ${ }^{14}$ This is a logical consequence of the fact that UN internships are unpaid. The United Nations is the largest and the most important international organization and for many students of international law, international relations and many other disciplines, working for the UN is a dream come true. Hence, they are willing to do the internship for free, pay for all the costs or even live in a tent during the internship. ${ }^{15}$ However, after some time, interns often find financially better options or just opt-out to take the next step outside of the UN. By paying interns, the United Nations would be able to keep the best experts within their own administration.

\subsection{Employment during the internship}

In addition to the fact that $\mathrm{UN}$ is not paying its interns, there is also the ban on taking any job during the internship. ${ }^{1617}$ Currently, the option for the hardest working people to take a job in order to cover the costs of their internship is also excluded as a possibility. ${ }^{18}$

Working alongside the internship would be a very demanding task - but let it be, at least as an option. The best candidates are not only the most educated or only the most intelligent ones - they have to be the hardest working as well. According to some studies, 5\% of the USA pop-

14 https://www.economist.com/blogs/economist-explains/2015/08/economist-explains-15, last visited 29 October 2017.

15 https://www.theguardian.com/global-development-professionals-network/2016/ aug/22/when-will-the-united-nations-address-its-unjust-internship-policy, last visited 29 October 2017.

16 http://www.aljazeera.com/indepth/opinion/2013/05/20135371732699158.html, last visited 29 October 2017.

17 https://careers.un.org/lbw/jobdetail.aspx?id=57411, last visited 29 October 2017.

18 http://www.undp.org/content/undp/en/home/operations/jobs/types-of-opportunities/internships.html, last visited 29 October 2017. 
ulation is working two or more jobs, with the apparent growing tendency. ${ }^{19}$ However, a statistic that is more relevant to the topic of this article is the one that focuses on the student population and their ability and willingness to multi-task and numbers are very convincing - over $80 \%$ of students are working while studying. ${ }^{20}$ According to another survey, conducted by NUS Services on behalf of Endsleigh, $77 \%$ of students work to fund their studies, with $63 \%$ having a part-time job and a third working during the term. ${ }^{21}$ No one can overlook the willingness of the young people to devote a lot of time and a lot of hard work for the career of their dreams. Working alongside UN internship, will make some interns to realize that that is too much for them. Without any doubt, some interns would drop out, but it is of the utmost importance to provide an option for that. The fact that we are living in the era of internet and wireless communication, where commuting is not necessarily part of the job makes the reasoning behind the decision not to allow jobs during the internship highly questionable. ${ }^{22}$

\section{INTERNSHIP IN PRIVATE SECTOR}

Unlike the United Nations, large companies in the private sector do not perceive their interns as a source of cheap (or more accurately free) labor force. Interns are seen as an enormous potential for the company an investment in the future. Behind this attitude there is no altruism or consideration for the wellbeing of young generations - but sheer benefit of the company. At least two aims are achieved this way: the employer has the opportunity to take into its system young, talented persons while their market value and demands are still low. Secondly, bringing interns of a young age into the company enables the employer to further develop their skills in accordance with the company's needs. This is why interns are paid in large and most successful corporations. Here are just several examples of the largest companies (ones from the information technology industry) and remuneration they are giving to their interns: Dropbox: $\$ 8,735 /$ month, Google: $\$ 7,185 /$ month, Facebook: $\$ 7,109 /$ month, Microsoft: $\$ 6,751 /$ month, Apple: $\$ 5,618 /$ month. $^{23}$

19 http://www.bls.gov/cps/cpsaat36.htm, last visited 29 October 2017.

20 http://www.marketwatch.com/story/nearly-4-out-of-5-students-work-2013-0807, last visited 29 October 2017.

21 https://www.theguardian.com/education/2017/mar/31/working-while-studyinghow-can-i-get-my-social-life-back, last visited 29 October 2017.

22 http://www.icty.org/x/file/jobs/Internship\%20Forms/internship_faqs_en.pdf, last visited 29 October 2016.

23 http://www.businessinsider.com/high-paying-tech-internships-2016-3, last visited 29 October 2017. 
Even if we put aside multi-billion I.T. corporations, many stateowned institutions and departments are also providing some kind of remuneration - often similar to the minimum wage, such as Public Defender Service. ${ }^{24}$ On the top of this, Public Defender Service offers other benefits as well. ${ }^{25}$ It is obvious that UN cannot match internship remuneration paid by the I.T. giants, but the culture of appreciation is something that the UN must nurture as well. Working within the UN system requires certain skills and it is different from almost any other job. Consequently, somebody coming to the UN in their middle age must go through a period of transition and adjustment to the system and this period is not needed for someone who started as an intern.

In this comparison with private enterprises, already-mentioned special status of the UN cannot be neglected. The United Nations is not a private enterprise whose sole interest is its own benefit and profit. The $\mathrm{UN}$ is a role-model, whose reputation rests on four pillars: impartiality, equity, efficiency and achievement - with a fifth one often added - independence. ${ }^{26}$ These values have to be incorporated within the internship policy as well.

\section{UN INTERNSHIP AS A ROAD TO A JOB}

There is a ban applied on employment in the UN for six months after the internship. The provision that indicates this practice states as following: "The Internship Programme is not related to employment in the United Nations. There should be no expectation of employment within the UN after an internship. Interns shall not be eligible to apply for, or be appointed to, positions at the professional level and above carrying international recruitment status in the Secretariat for a period of six months following the end of their internship." 27

The above-cited provision is a general rule for all UN-related internships - no expectations of employment. Purpose of this provision is to decrease the connection between the internship and the UN employment. If the UN internship really did not increase the chance of UN employment, then the fact that the internship is not paid would still be wrong, but without such drastic consequences for both the UN and interns.

24 http://www.pdsdc.org/careers/criminal-law-internship-program, last visited 29 October 2017.

25 Ibid.

26 M. Froehlich, Political Ethics and the United Nations: Dag Hammarskjöld as Secretary-General, Routledge, 2007, 205.

27 http://www.unescap.org/jobs/internships-faqaccessed, last visited 29 October 2017. 
However, the fact that internships can lead to UN employment (in practice, often the first step after an internship is a consultant position) is obvious from the description of the duties and obligations of the interns. For example, it is stated that the intern will be "...working directly with outstanding and inspiring career professionals and senior management". ${ }^{28}$ Even general provision states: "The objective of the internship is to give you a first-hand impression of the day-to-day working environment of the United Nations. You will be given a real chance to work with our people. As part of our team, working directly with outstanding and inspiring career professionals and senior management, you will be exposed to highprofile conferences, participate in meetings, and contribute to analytical work as well as organizational policy of the United Nations. Initially you will take on the amount of responsibility you can shoulder; the potential for growth, however, is yours to develop". ${ }^{29}$ Provisions enabling interns to acquire valuable connections during the course of the internship are not restricted to the general documents, but can also be found in the localized policies. One of the features of the UN internship in the USA includes "inviting members of the United Nations, Permanent mission to the U.N. and UNA-USA senior staff to address subjects determined by the interns". 30

It is obvious that there is a possibility for a good and hardworking intern to create a network that would help him in the future career. There is nothing wrong to give an intern the possibility to create networks and hence pave the way to the UN appointment. Moreover, this is what an internship should look like and it should present a possibility for the best interns to stay permanently in the UN system. However, the issue lies within the fact that this opportunity is given only to those wealthy enough or ones living within the vicinity of the UN offices providing the internship programs.

\section{POTENTIAL SOLUTIONS}

Criticisms coming from numerous organizations and individuals regarding this unfair internship practice are not by any means new, but these voices have been raised more often in recent years. Even former US president Barak Obama raised his voice against unpaid internship in the USA. ${ }^{31}$ The United Nations response to these complaints is rather contro-

28 https://careers.un.org/lbw/home.aspx?viewtype $=I P$, last visited 29 October 2017.

29 Ibid.

30 S. Hamadeh, Vault Guide to Top Internships, Vault, 2004, 402.

31 Brann \& Isaacson, "Hiring Unpaid Interns: Advice for Employers", Maine Employment Law Letter 2011, 4. 
versial. The General Assembly resolution banning the payment of interns was stated as the formal reason that prevents UN from amending the nonpayment practice. Later, it was revealed that there is no rule vested in a resolution preventing financial aid to interns. ${ }^{32}$ Only such provision might be the one that places interns in the "gratis personnel" classification. However, there is absolutely no provision that forbids the UN from altering their status or changing the classification. The position and duties of interns have evolved over time and their role is much different now than when the "gratis personnel" class was formed. From a financial standpoint, the United Nations insisted that there are simply no funds available to be allocated for interns. However, the Secretariat recently filed a request to the General Assembly, recommending the raise of the staff wages for $10 \% .{ }^{33}$ Obviously, there are possibilities for allocation of more funds to the (not so low) UN staff wages. According to some estimates, covering all interns' costs would require less than $0.5 \%$ of the current UN budget. ${ }^{34}$ Many other international agencies solved this issue despite the fact that they have much smaller budgets. One can take as an example the ILO (that has budget of $801.860 .000 \$ \$^{35}$ compared to the UN's 5,4 billion dollars ${ }^{36}$ ), which made a significant changes to its policy. The ILO provision regarding internship states that "where an intern is not supported by an institution (university, government or other institution), a stipend to cover basic subsistence costs will be paid by the ILO." ${ }^{" 37}$ Furthermore, Interpol is remunerating 550 EUR per month for the interns in Lyon and similar contribution is provided to the interns stationed in different duty stations. ${ }^{38}$

Ideas for amending the UN internship policy are numerous but crucial element in this endeavor is still questionable - is there a will for the change within the United Nations' administration? In order to introduce paid internship positions there are at least two applicable models that would demand fewer funds than financing every intern. One option is to

32 https://www.theguardian.com/global-development-professionals-network/2016/ aug/22/when-will-the-united-nations-address-its-unjust-internship-policy, last visited 29 October 2017.

33 https://www.theguardian.com/global-development-professionals-network/2016/ aug/22/when-will-the-united-nations-address-its-unjust-internship-policy, last visited 29 October 2017.

34 Ibid.

35 The Director-General's Programme and Budget Proposals For 2016-17, 323rd Session, Geneva, 12-27 March 2015, 69.

36 Fifth Committee (Administrative and Budgetary) budget for the United Nations for the 2016-2017 biennium.

37 http://www.ilo.org/public/english/bureau/pers/vacancy/intern.htm\#q4, last visited 29 October 2017.

38 https://www.interpol.int/Footer-extranet/Recruitment/Other-recruitment-pages/ Internships, last visited 29 October 2017. 
provide paid internship only for candidates coming from the poorest countries. The list of those countries does not need to be created - the UN can use its list of the LDC's, which currently has 47 countries within. ${ }^{39}$ The second option that would be in line with the UN standards would be establishing paid intern positions for the best candidates, regardless of their (or their countries') economic status.

Apart from those, in author's opinion the fastest and the most practical ways of amending current internship policy, there are at least two more options, but one of them requires a lot of time and the other one a lot of effort and "tectonic" changes within the UN system. The first idea is to give more time to the UN to develop and eventually establish the practice of remunerating interns. Although these processes within the UN system can be very lengthy, there are examples of changes being made over a time. Good example is the one of the colonial countries. ${ }^{40}$ Those countries had lengthy independence struggle before and after the World War II, ${ }^{41}$ but at the end through numerous resolutions, the United Nations paved the path to their independence. The second option is the reform of the entire UN system. It is obvious that UN system is in desperate need of a change - the only question is how big the overhaul should be and how to achieve it. Some authors suggest that the reform should start from the Security Council ${ }^{42}$ others are proposing the reform of the appointment procedure of the Secretary General ${ }^{43}$ or advocating for some other solutions. ${ }^{44}$ However, in order to analyze alteration of the internship policy within the more comprehensive change of the UN system, separate and much bigger and more detailed analysis is needed.

\section{CONCLUSION}

As it was already pointed out in this article, understanding the importance of interns and respecting their contribution is a very important task. The UN has an added level of responsibility towards young people

39 https://www.un.org/development/desa/dpad/least-developed-country-category. html, last visited 29 October 2017.

40 Colonial countries are countries of origin of many "potential" interns that are currently in disadvantage.

41 B. Milisavljević, "Diplomatska zaštita u međunarodnom pravu i Ujedinjene nacije”, Zbornik Matice srpske za društvene nauke 4/2013, 672.

42 More on that in D. Dimitrijević, Reforma Saveta bezbednosti Ujedinjenih nacija, Institut za međunarodnu politiku i privredu, Beograd 2009.

43 More on that in M. Novaković, "Some Remarks Regarding the Procedure of the Appointment of the Secretary General of the United Nations", Annals of the Faculty of Law in Belgrade 3/2016, 171-191.

44 More on that in J. Muller (ed.), Reforming the United Nations - The Struggle for Legitimacy and Effectiveness Martinus Nijhoff Publishers, Leiden - Boston, 2006. 
- because of the UN's role-model position to many organizations, states and even individuals. The United Nations constantly emphasizes the importance of achieving equality in various fields ${ }^{45}$ and we can see this aim proclaimed within the Sustainable Development Goals in goal number $10^{46}$ and especially within the goal 4.5 . Goal number 4.5., stresses the need to "eliminate gender disparities in education and ensure equal access to all levels of education and vocational training for the vulnerable, including persons with disabilities, indigenous peoples, and children in vulnerable situations" ${ }^{47}$ The United Nations cannot fail at the first step, in the first contact with young people - and the internship is just that. The organization of the United Nations must be the prime example of the implementation of the values ${ }^{48}$ that it advocates for. Providing an equal opportunity for all young people is beneficial and important not only for young people around the world striving towards working in the UN (or at least familiarizing with its system), but also for the United Nations as an organization.

\section{REFERENCES}

Browne, S., Sustainable Development Goals and UN Goal-Setting, Routledge, 2017.

Dimitrijević, D., Reforma Saveta bezbednosti Ujedinjenih nacija, Institut za međunarodnu politiku i privredu, Beograd 2009.

Dodd, E. M., "The Supreme Court and Fair Labor Standards 1941-1945", Harvard Law Review 59/1946.

Durrant, C.,"To Benefit or Not to Benefit: Mutually Induced Consideration as a Test for the Legality of Unpaid Internships", University of Pennsylvania Law Review 162/2013.

Faiza, S., "Inequality Within and Among Countries", International Norms, Normative Change, and the UN Sustainable Development Goals (ed. Noha Shwaki), Lexington Books, 2016.

Fitzpatrick, L., “The Minimum Wage”, Time, July 24/2009.

45 T. G. Weiss et al., The United Nations and Changing World Politics, Westview Press, 2016, 388.

46 S. Faiza, "Inequality Within and Among Countries", International Norms, Normative Change, and the UN Sustainable Development Goals (ed. N. Shwaki), Lexington Books, 2016, 104.

47 S. Yamada, “Asian Regionality and Post-2015 Consultation: Donors' Self-Images and the Discourse", Post-Education-Forall and Sustainable Development Paradigm: Structural Changes with Diversifying Actors and Norms (ed. A. Wiseman), Emerald Group Publishing Limited, 2016, 115

48 S. Browne, Sustainable Development Goals and UN Goal-Setting, Routledge, 2017, 108 . 
Fomerand, J., The A to $Z$ of the United Nations, The Scarecrow Press 2009.

Froehlich, M., Political Ethics and The United Nations: Dag Hammarskjöld as Secretary-General, Routledge, 2007.

Hamadeh, S., Vault Guide to Top Internships, Vault 2004.

Milisavljević, B.,"Diplomatska zaštita u međunarodnom pravu i Ujedinjene nacije", Zbornik Matice srpske za društvene nauke 4/2013.

Novaković, M., "Some Remarks Regarding the Procedure of the Appointment of the Secretary General of the United Nations", Annals of the Faculty of Law in Belgrade 3/2016.

Weiss, T. G., et al., The United Nations and Changing World Politics, Westview Press, 2016.

Yamada, S., "Asian Regionality and Post-2015 Consultation: Donors' Self-Images and the Discourse", Post-Education-Forall and Sustainable Development Paradigm: Structural Changes with Diversifying Actors and Norms (ed. A. Wiseman), Emerald Group Publishing Limited, 2016.

Carter, J., Boutros-Ghali, B. (eds.), Conference for Global Development Cooperation: Meeting Report, DIANE Publishing, 1992.

Brann \& Isaacson, "Hiring Unpaid Interns: Advice for Employers", Maine Employment Law Letter 2011.

Muller, J. (ed.), Reforming the United Nations - The Struggle for Legitimacy and Effectiveness, Martinus Nijhoff Publishers, Leiden - Boston, 2006.

Article history: Received: 30. 10. 2017. Accepted: 29. 12. 2017. 